\title{
Street Vending in the Eastern Cape: Survival Strategy or Conduit to Entrepreneurship?
}

\section{Mahadea}

School of Business, University of Natal

\section{ABSTRACT}

Although South Africa consistently registered positive economic growth rates since the democratic government took office in 1994, this economic expansion has not been accompanied by a surge of new formal sector jobs. The public and private sectors have been shedding labour, partly in response to globalisation and domestic economic realities. Consequently, more and more individuals are taking to street vending to create jobs for themselves. This article examines the dynamics of street vending and investigates whether it is merely a survival mode of existence or a conduit to formal entrepreneurship. The results of the study indicate that only 15 per cent of the surveyed operators may graduate to formal entrepreneurship in the medium or long term. It seems highly unlikely that a substantial number of high profile entrepreneurs would emerge from this mass of survivalist traders. For most street traders, the informal economy is not a conduit to entrepreneurship, but a survival strategy. From a development perspective, the way forward for street vendors is to transform their ventures into more value-adding operations that can provide sustainable livelihoods for themselves, and in due course jobs for others.

JEL E24, J60, 017

\section{INTRODUCTION}

South Africa consistently registered positive economic growth rates in the five years 1995-2000, ranging from 3.4 per cent in 1995 to 2 per cent in 1999 and 3 per cent in 2000 (SARB, March 2001). Although this post-apartheid growth performance is significantly higher than the 1 per cent average growth rate over the 1985-1994 period, this economic expansion has not been accompanied by a surge of new jobs. This pattern of output growth without a major expansion in formal sector employment is presently a troubling aspect of the South African economy. The country has produced a striking case of jobless growth, although some success has undoubtedly been achieved in the provision of basic services to disadvantaged communities and in meeting certain elements of the government's growth, employment and redistribution strategy (GEAR). The 
unemployment rate (expanded definition) increased from 31.5 per cent in 1994 to 37.5 per cent in 1998 , despite the GEAR program. In terms of the official definition, the unemployment rate increased from 20.3 per cent to 25.2 per cent over the same period, and to 26.4 per cent in 2001 (Stats SA, 2001)

While unemployment across South Africa has remained a serious problem, in the former Transkei (part of Eastern Cape province), unemployment and its associated poverty is apparently much worse than 5 years ago (Mahadea, 2001). This situation follows from the closure of previously subsidised industries in the $1990 \mathrm{~s}$, the restructuring of public sector corporations, and the relocation of the administrative capital with its government offices from Umtata to Bisho.

At the national level, efforts to enhance competitiveness and exert fiscal discipline have led to restructuring and hence downsizing or rightsizing in both public and private sector employment. In effect, some 187000 jobs have been lost between the first quarter of 1997 and 1998 (SARB, 1998), and another 81 000 formal sector jobs lost from December 1998 to September 1999 (SARB, March 2000). Comparing the average employment level in the first threequarters of 2000 with that of the corresponding period in 1999 , there was a further annual decline of 2.7 per cent in formal sector employment (SARB, March 2001). Given its thin industrial base, the Transkei area is especially vulnerable to any public sector squeeze on jobs.

Furthermore, trade union actions and stringent labour legislations have reduced the scope for much-needed labour market flexibility for employment creation (The Economist, 10/2/01: 75). In 2000, for instance, 500000 workdays were lost owing to strikes and work stoppage actions (SARB, March 2001). As the labour absorption capacity of the formal economy has been declining steadily and dangerously, to under 10 per cent of the total adult population in the late 1990 s and early 2000 s, more and more people are turning to informal sector entrepreneurship for employment. The GDP elasticity of formal employment was a negative 0.55 during the period 1990-1996, confirming the view that new employment growth would be most likely to emerge from the informal economy (Loots, 1998).

Small-scale entrepreneurship is one occupation available to many individuals. Recent growth in self-employment and informal sector trading raises some key questions. Can the informal sector be the sponge to realistically absorb the flood of new entrants into the labour market? Would there be a critical mass of operators moving out of informal activities and graduating to formal entrepreneurship over time? Is street vending in urban centres becoming a permanent mode of survivalist activity for operators? What are the characteristics, conduct and performance of the street enterprises run by men 
and women in their attempts to gain a livelihood outside the formal economy? Can one infer that problems and prospects of male operators are the same as those of their female counterparts in different urban places in the Eastern Cape? Beyond these practical issues lies the central policy question: can the informal sector provide a lasting solution to unemployment? At present there is 'only a poor understanding' (Kaplinsky, 1990: 45) of the underdeveloped situation of informal sector activity in South Africa.

This paper seeks to shed more light on the street vending part of the informal sector and to advance our appreciation of its role in the South African economy. Based on a survey of 475 street vendors from four towns in the Eastern Cape province, the results of the study may provide some answers to the above questions.

The paper consists of four parts. The first briefly examines the economic and development studies literature on the informal sector. The second describes the research methodology process. The third presents and discusses the survey results. The last section offers concluding remarks regarding street vending in the Eastern Cape as a survival strategy or conduit to entrepreneurship.

\section{THE INFORMAL SECTOR AND ECONOMIC SIGNIFICANCE}

There is no generally accepted definition of the informal sector. The informal economy is an "utterly fuzzy concept" (Peattie, 1987: 851), with many faces (Preston-Whyte \& Rogerson, 1991: 146). According to Nattrass (1987: 863) the informal sector consists "of all people outside formal wage employment in the large-scale officially recognised and regulated sector, as well as all enterprises which function outside government rules and regulations and which operate on a small scale using labour-intensive technology". In many countries, including South Africa, the informal sector is regarded mainly as a survival strategy for the poor, and an alternative path to development outside the mainstream economy (Elson \& Pearson, 1997). The World Bank seems to believe that the informal sector (with low capital intensity) would be the dominant source of growth in the manufacturing industry in Africa (Agarwala, 1990: 164).

Although the informal sector contributes significantly to meeting some lowincome basic needs and generating employment opportunities at low cost, all micro-firms are not high value-adding ventures, and their ways of "doing things" are not homogenous (Peattie, 1987). Informal sector operators are engaged in a wide range of legal and illegal activities, some in socially and economically low productivity activities. Many are led by women, often assisted by extended family members. These enterprises may be distinguished 
in terms of ease of entry, reliance on locally available resources, family ownership, labour-intensive and adapted technology, skills acquired outside the formal school system, and markets that are unregulated and competitive (ILO, 1972).

The lives of the majority of ordinary South Africans have somehow been touched by the informal economy in recent times (Rogerson \& Preston-Whyte, 1991: 1). Many individuals, migrating from rural to urban areas in search of employment and attractions of city life, end up in informal employment activities, ranging from pirate taxi driving, to hawking, street vending and shebeening. The rising unemployment is, no doubt, forcing many others to engage in crime, prostitution and drug activities. Driven by the necessity to survive, a top policy maker argued that some South Africans are "forced to beg, rob and murder to ensure that they and their own do not perish from hunger" (The Economist, 1999).

The informal sector in South Africa is estimated to contribute between 6 and 12 per cent to the country's gross domestic product (GDP), (Kirsten \& Sindane, 1994; Abedian \& Desmidt, 1990); recent trends indicate that this contribution is increasing. The Bureau of Market Research (BMR) (1996) indicated that this 'grey' economy contributed 6.7 per cent to the GDP in 1994; in terms of value added this represents an estimated R26 billion. But according to the 1995 Central Statistical Service (CSS) household survey, the informal sector contributed R32.4 billion a year to GDP, about 7 per cent of total value added in the economy.

With regard to employment, almost 1.6 million people, i.e. about 15.4 per cent of the labour force in South Africa were employed in the informal sector (BMR, 1996). The 1995 CSS household survey indicated that at least 1.74 million were engaged in this underground sector, making a monthly contribution of R2.7 billion to the economy in terms of goods and services. The 1998 October Household Survey indicated that overall employment increased from 9.3 million in October 1996 to 9.4 million in October 1998, resulting largely from "prominent increases in informal-sector employment" (SARB, June 2000). Indeed, according to the most recent national Household Surveys, between 1996 and 1999 informal employment increased from 1 million to 1.9 million in 2000 (Financial Mail, 29 June, 2001). The February 2001 Labour Force Survey indicates that the jobs in the informal sector increased from 1.9 million in 2000 to 2.7 million in 2001 .

On the income side, the eamings of the "underground" operators in South Africa vary considerably. The 1995 CSS study indicates that average salary in the informal sector is below R500 monthly. But within the informal sector, some 
individuals are engaged in criminal or socially unacceptable activities, such as armed robberies, drug trafficking and hijackings. Certainly, the pay-off from such high-risk activities are high, to the extent that individuals engaged therein are not always brought to justice (Baumol, 1990). These villainous aspects of entrepreneurship do not contribute to society's welfare. However, most lawabiding citizens in the informal sector prefer to earn income through decent means. Accordingly, the informal sector has pockets of both comfortably off and poor people.

\section{RESEARCH METHOD}

Against the background of rising unemployment and worsening poverty, this study examined the employment creation potential and dynamics of street vending entrepreneurship in the Eastern Cape province. It was conducted by means of a random sample survey. The sample consisted of 475 street traders, proportionally drawn from the four main urban centres of the northern half of Eastem Cape (Umtata, Butterworth, King Williamstown (KWT) and East London). Sampling was done in proportion to town populations: accordingly, 214 street vendors were randomly selected from East London, 114 from KWT, 107 from Umtata and 40 from Butterworth.

The subjects were 346 female and 129 male micro-traders. Data was obtained by means of questionnaire-based interviews. The questionnaire was tested initially on a sub-sample of 50 traders in the surveyed areas. It sought information on the socio-economic attributes of the respondents, their access to start-up and development finance, sales, job creation and perceived business prospects as well as business needs. The questionnaires were then administered in all the surveyed areas, with the help of research assistants and translators.

\section{RESULTS}

\subsection{Socio-Economic Characteristics}

\subsubsection{Marital status and migration}

Females dominate street vending. About three-quarters of the surveyed traders were female ( 72.8 per cent). With regard to their marital status, the majority ( 54 per cent) was single, 27 per cent were married, 3 per cent were cohabiting and the remainder were either divorced or separated.

Although all the vendors in the four cities were trading on the streets near the 
taxi/bus ranks, markets and shopping complexes, nearly all of them were living outside the trading location and their birth districts, reflecting that there was substantial provincial migration to the towns. Of the 475 traders, 304 (64 per cent) were internal migrants within the province, 139 (29 per cent) were born in the district of the interview, only 13 (2.7 per cent) were born in another province of South Africa, and 19 (4 per cent) were born outside South Africa. This pattern of internal migration tends to be in line with the Harris-Todaro model (Ingham, 1995), in that many unemployed individuals left low-productivity subsistence agriculture activities of rural areas for jobs in the urban areas. There was a small proportion ( 4 per cent) of 'international' migrants, all males originating from neighboring African countries, Nigeria, Sierra Leone and Senegal, and from Pakistan. They claimed to have refugee status in South Africa. About two thirds ( 65.5 per cent) were residing in townships, about a quarter (23.5 per cent) in rural locations, another 9 per cent in squatter camps and the remainder inhabited areas close to their trading cities.

\subsubsection{Dependants}

Table 1 Street traders and number of dependants

\begin{tabular}{|l|c|c|c|c|c|c|c|}
\hline Gender & $\begin{array}{c}\text { No } \\
\text { Child }\end{array}$ & $\begin{array}{c}1-2 \\
\text { Chil- } \\
\text { dren }\end{array}$ & $\begin{array}{c}3-4 \\
\text { Chil- } \\
\text { dren }\end{array}$ & $\begin{array}{c}5-6 \\
\text { Chil- } \\
\text { dren }\end{array}$ & $\begin{array}{c}7-8 \\
\text { Chil- } \\
\text { dren }\end{array}$ & $\begin{array}{c}9 \text { \& More } \\
\text { Children }\end{array}$ & Total \\
\hline Female & $\begin{array}{c}28 \\
(5.8 \%)\end{array}$ & $\begin{array}{c}92 \\
(19.4 \%)\end{array}$ & $\begin{array}{c}93 \\
(19.6 \%)\end{array}$ & $\begin{array}{c}84 \\
(17.7 \%)\end{array}$ & $\begin{array}{c}30 \\
(6.3 \%)\end{array}$ & $\begin{array}{c}19 \\
(4 \%)\end{array}$ & $\begin{array}{c}346 \\
(73 \%)\end{array}$ \\
\hline Male & $\begin{array}{c}28 \\
(5.8 \%)\end{array}$ & $\begin{array}{c}36 \\
(7.6 \%)\end{array}$ & $\begin{array}{c}29 \\
(6.1 \%)\end{array}$ & $\begin{array}{c}29 \\
(6.1 \%)\end{array}$ & $\begin{array}{c}4 \\
(0.8 \%)\end{array}$ & $\begin{array}{c}3 \\
(0.6 \%)\end{array}$ & $\begin{array}{c}129 \\
(27 \%)\end{array}$ \\
\hline TOTAL & $\begin{array}{c}56 \\
(11.6 \%)\end{array}$ & $\begin{array}{c}128 \\
(27 \%)\end{array}$ & $\begin{array}{c}122 \\
(25.7 \%)\end{array}$ & $\begin{array}{c}113 \\
(23.8 \%)\end{array}$ & $\begin{array}{c}34 \\
(7.1 \%)\end{array}$ & $\begin{array}{c}22 \\
(4.6 \%)\end{array}$ & $\begin{array}{c}475 \\
(100 \%)\end{array}$ \\
\hline
\end{tabular}

(Figures are rounded off to 1 decimal place)

Many individuals engage in informal trading as a survival strategy, enabling them to support their dependants. Only 11.6 per cent of the respondents had no children (Table 1), while 76 per cent had between one and six children to support, and about 5 per cent had nine or more children to maintain. The traders were supporting, on average, four children. 


\section{Figure 1 Age distribution}

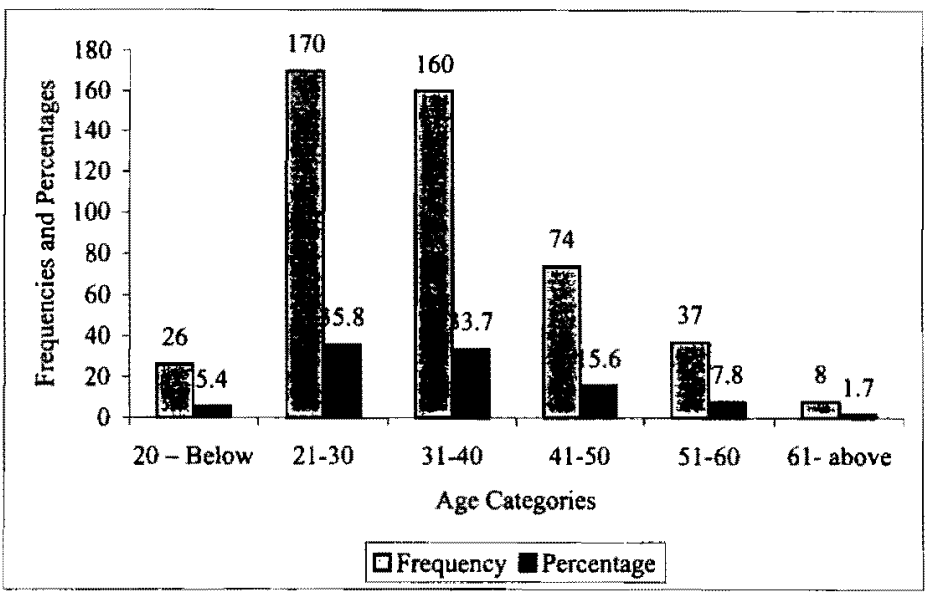

\subsubsection{Age}

The age distribution of the street vendors ranged from under 20 ( 5.5 per cent) to over 60 ( 1.7 per cent), with 36 per cent in the $21-30$ group, 34 per cent in the 31 40 category and another 23 per cent in the $41-60$ age group (Figure 1). Thus, about 70 per cent fall in the most productive and fertile period (21-40) of the human life-cycle. The mean age of the respondents was 35 years.

\subsubsection{Education}

The urban micro traders have varying levels of education. Of the 475 traders, 8 per cent had grades 4-5 education, 19 per cent had between grades 6 and 7, another 30 per cent had between grades 8 and 9, 20.8 per cent had between grades 10 and 11 , and the remainder had a matric or higher level of education. Figure 2 below compares the education levels of males and females, and it reflects that proportionally, females have higher educational levels than males. About a third (113 females and 44 males) of the traders surveyed, had an education of standard 8 and above. At the grade 8-9 level, the proportion of males having that level of education was 25 per cent, whereas for females the figure was 32 per cent, and at grades $6-7$, the proportion for females was 20.5 per cent and that of male 13.2 per cent. The mean education standard attained by the respondents was between grades 8 and 9 , reflecting a low level of acquired human capital. 


\section{Figure 2 Gender and level of education}

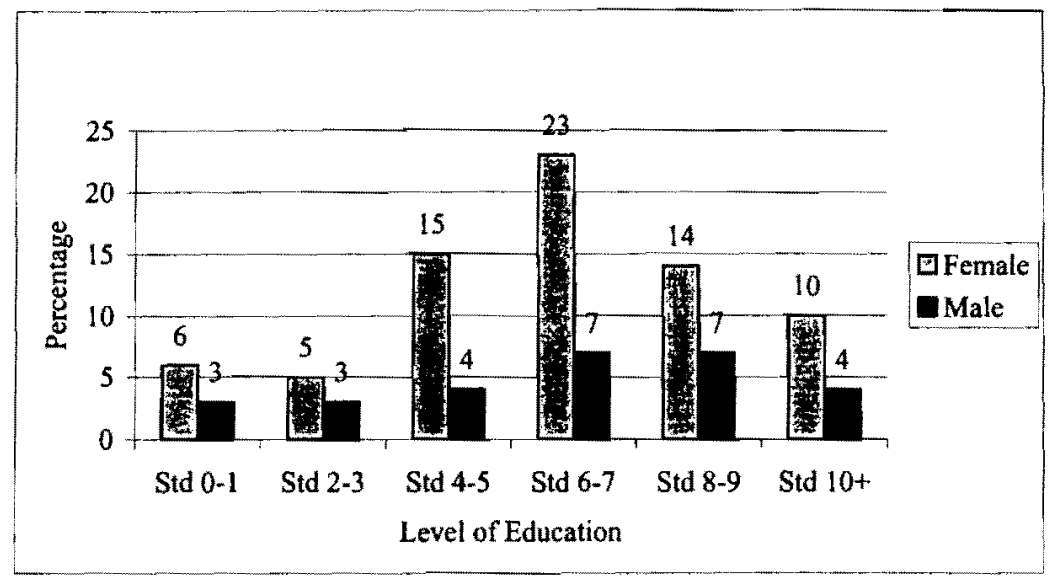

\subsubsection{Training}

As far as formal skill training is concerned, over four fifths ( 81 per cent) of the respondents had no exposure to any form of training (Table 2). However, 11 per cent (46 females and 9 males) had received training in tailoring and sewing, 1 per cent in bricklaying and 0.4 per cent in small business management. The mean duration of formal training was only two months.

Table 2 Gender and skills training

\begin{tabular}{|l|c|c|c|c|c|c|}
\hline Gender & $\begin{array}{c}\text { No } \\
\text { training }\end{array}$ & $\begin{array}{c}\text { Sewing/ } \\
\text { tailoring }\end{array}$ & $\begin{array}{c}\text { Brick } \\
\text { laying }\end{array}$ & $\begin{array}{c}\text { Small } \\
\text { business }\end{array}$ & Others & Total \\
\hline Female & $\begin{array}{c}285 \\
(60 \%)\end{array}$ & $\begin{array}{c}46 \\
(9.7 \%)\end{array}$ & 0 & 0 & $\begin{array}{c}15 \\
(3.16 \%)\end{array}$ & $\begin{array}{c}346 \\
(73 \%)\end{array}$ \\
\hline Male & 100 & 9 & 6 & 2 & 12 & 129 \\
& $(21 \%)$ & $(1.89 \%)$ & $(1.26 \%)$ & $(0.42 \%)$ & $(2.53 \%)$ & $(27 \%)$ \\
\hline TOTAL & $\begin{array}{c}385 \\
(81 \%)\end{array}$ & $\begin{array}{c}55 \\
(11.6 \%)\end{array}$ & $\begin{array}{c}6 \\
(1.26 \%)\end{array}$ & $\begin{array}{c}2 \\
(0.42 \%)\end{array}$ & $\begin{array}{c}27 \\
(5.7 \%)\end{array}$ & $\begin{array}{c}475 \\
(100 \%)\end{array}$ \\
\hline
\end{tabular}

\subsection{Motives for Venturing into Street Trading}

A mixture of push and pull factors attracts individuals to start a business of their own. In this study, the overwhelming majority of the traders were pushed into street vending because of a lack of wage employment opportunities in the Eastern Cape, and the need to support their families, having little or no 
alternative source of income. Specifically, of the 475 vendors, 62 per cent stated that lack of stable employment was a problem, 20 per cent mentioned the need to find money to support their families, 5 per cent had been retrenched and another 2 per cent had resigned from their previous employment (Table 3 ). Overall, therefore, almost 90 per cent of the respondents were thrust into street trading businesses as a subsistence strategy for themselves and their families.

\section{Table 3 Motives for starting informal trading}

\begin{tabular}{|l|c|c|c|c|c|c|c|}
\hline Gender & $\begin{array}{c}\text { No stable } \\
\text { wage emp. }\end{array}$ & $\begin{array}{c}\text { Support } \\
\text { family }\end{array}$ & $\begin{array}{c}\text { Start } \\
\text { business }\end{array}$ & $\begin{array}{c}\text { Re- } \\
\text { trenched }\end{array}$ & Resigned & Other & Total \\
\hline Female & $\begin{array}{c}219 \\
(46 \%)\end{array}$ & $\begin{array}{c}77 \\
(16 \%)\end{array}$ & $\begin{array}{c}24 \\
(5 \%)\end{array}$ & $\begin{array}{c}13 \\
(3 \%)\end{array}$ & $\begin{array}{c}5 \\
(1 \%)\end{array}$ & $\begin{array}{c}8 \\
(2 \%)\end{array}$ & $\begin{array}{c}346 \\
(73 \%)\end{array}$ \\
\hline Male & 76 & 76 & 19 & 18 & 3 & 4 & 129 \\
& $(16 \%)$ & $(16 \%)$ & $(4 \%)$ & $(4 \%)$ & $(1 \%)$ & $(1 \%)$ & $(27 \%)$ \\
\hline TOTAL & $\begin{array}{c}295 \\
(62 \%)\end{array}$ & $\begin{array}{c}96 \\
(20 \%)\end{array}$ & $\begin{array}{c}42 \\
(9 \%)\end{array}$ & $\begin{array}{c}22 \\
(5 \%)\end{array}$ & $\begin{array}{c}8 \\
(2 \%)\end{array}$ & $\begin{array}{c}12 \\
(3 \%)\end{array}$ & $\begin{array}{c}475 \\
(100 \%)\end{array}$ \\
\hline
\end{tabular}

There were, however, almost 9 per cent (42) of the surveyed individuals who went into street trading by choice, drawn by pull factors to start their own ventures. Comparing the motives of males and females, it was found that lack of stable employment and the need to earn income to support the family, were key factors motivating the individuals to engage in street vending in the urban areas in the Eastern Cape. Most of these people stay in the informal sector by obligation rather than by choice.

Among those who had some exposure to formal employment prior to engaging in street vending, 108 individuals (about 23 per cent) were labourers, another 81 (17 per cent) were domestic workers, 15 (3 per cent) were security guards and 29 (6 per cent) were salespersons. Some gender occupational discrimination was present here, in that a concentration of women were domestic workers, labourers and sales individuals. These categories of jobs require little formal education and training, and until recently, have had little formal legal protection and security. The average duration of formal employment of the surveyed individuals was 2.4 years, and the average monthly income received by them was R188 during these 2.4 years.

A high proportion of the respondents had never been in any wage employment before. Specifically, about 49 per cent of the micro-traders had no exposure to wage labour at all. Furthermore, females were more adversely placed; in absolute terms 174 females ( 50.3 per cent) and 57 males ( 44 per cent) had no former exposure to wage employment at all. However, there was a higher 
proportion of females ( 16.8 per cent) in wage employment for 3-4 years than males ( 15 per cent).

Although a high proportion of the surveyed traders was without any exposure to the formal sector employment, this does not mean that all the individuals had not searched for employment. Of those who sought wage employment, 10 per cent searched for a period of 1 month or less, 20 per cent searched for 2-3 months, about 9 per cent searched for 4-5 months and another 30 per cent looked for wage employment for over a year (Table 4). The average duration of their search was 9.9 months. The majority of the respondents searched for jobs over long distances, and for varying duration, within the same province. Their search locations were essentially local or provincial, because of resource and network limitations. Only 6.7 per cent of the surveyed individuals searched for jobs outside the Eastern Cape, and this group comprised of 15 males and 17 females.

Table 4 Months looking for wage employment

\begin{tabular}{|c|c|c|}
\hline Duration (Mths) & Frequency & Percentage \\
\hline 0 & 103 & 21.7 \\
\hline $1-$ less & 51 & 10.7 \\
\hline $2-3$ & 94 & 19.8 \\
\hline $4-5$ & 41 & 8.6 \\
\hline $6-7$ & 24 & 5.1 \\
\hline $8-9$ & 12 & 2.5 \\
\hline $10-11$ & 8 & 1.7 \\
\hline $12+$ & 144 & 30.3 \\
\hline
\end{tabular}

The above seem to confirm the severity of the unemployment problem in the Eastern Cape. Many internal migrants, against their wishes, have never had wage employment, despite undergoing months of protracted search processes both in cities of the Eastern Cape province (55.4 per cent) and in other provinces (23 per cent). To find sustenance, 'most of these individuals became 'discouraged workers' and took refuge into urban street vending activities.

\subsection{Nature of Business Activity}

Street vendors are engaged in a range of activities. They operate on streets and pavements at taxi ranks, around shopping complexes, and at certain other public places. The surveyed traders were dealing in fruit and vegetables, cooked food, drinks, raw meat, shoe repairs, ornaments and toys, and traditional medicine. 
Table 5 Nature of informal street trading business

\begin{tabular}{|l|c|c|c|c|c|c|c|c|}
\hline Gender & $\begin{array}{l}\text { Frults \& } \\
\text { veg }\end{array}$ & $\begin{array}{l}\text { Food \& } \\
\text { drinks }\end{array}$ & $\begin{array}{l}\text { Cloth \& } \\
\text { wears }\end{array}$ & $\begin{array}{l}\text { Orna \& } \\
\text { toys }\end{array}$ & $\begin{array}{l}\text { Shoe } \\
\text { repairs }\end{array}$ & $\begin{array}{l}\text { Trad. } \\
\text { med. }\end{array}$ & Others & Total \\
\hline Female & $\begin{array}{c}140 \\
(29.5 \%)\end{array}$ & $\begin{array}{c}99 \\
(20.8 \%)\end{array}$ & $\begin{array}{c}73 \\
(15.4 \%)\end{array}$ & $\begin{array}{c}31 \\
(6.8 \%)\end{array}$ & $\begin{array}{c}1 \\
(0.2 \%)\end{array}$ & $\begin{array}{c}(0.4 \%) \\
(0.4 \%)\end{array}$ & 0 & $\begin{array}{c}346 \\
(73 \%)\end{array}$ \\
\hline Male & $\begin{array}{c}9 \\
(1.9 \%)\end{array}$ & $\begin{array}{c}26 \\
(5.5 \%)\end{array}$ & $\begin{array}{c}41 \\
(8.6 \%)\end{array}$ & $\begin{array}{c}35 \\
(7.4 \%)\end{array}$ & $\begin{array}{c}9 \\
(1.9 \%)\end{array}$ & $\begin{array}{c}6 \\
(1.3 \%)\end{array}$ & $\begin{array}{c}3 \\
(0.6 \%)\end{array}$ & $\begin{array}{c}129 \\
(27 \%)\end{array}$ \\
\hline Total & $\begin{array}{c}149 \\
(31.4 \%)\end{array}$ & $\begin{array}{c}125 \\
(26.3 \%)\end{array}$ & $\begin{array}{c}114 \\
(24 \%)\end{array}$ & $\begin{array}{c}66 \\
(14.2 \%)\end{array}$ & $\begin{array}{c}10 \\
(2.1 \%)\end{array}$ & $\begin{array}{c}8 \\
(1.7 \%)\end{array}$ & $\begin{array}{c}3 \\
(0.6 \%)\end{array}$ & $\begin{array}{c}475 \\
(100 \% \\
)\end{array}$ \\
\hline
\end{tabular}

A proportionately smaller number of the vendors were trading in shoe repairs and traditional medicine. The majority of the traders were involved in fruits and vegetables ( 31.4 per cent) and food and drinks ( 26.3 per cent) (Table 5). About half of the female vendors concentrated in these two categories of trade, reflecting ease of entry in terms of skills and capital and some elements of gender specialisation.

Table 6 Distribution of street business activity by regions

\begin{tabular}{|c|c|c|c|c|c|c|c|c|}
\hline Regions & $\begin{array}{c}\text { Fruits } \\
\text { \& veg }\end{array}$ & $\begin{array}{c}\text { Food \& } \\
\text { drink }\end{array}$ & $\begin{array}{c}\text { Cloth } \\
\text { \& wear }\end{array}$ & $\begin{array}{c}\text { Orna \& } \\
\text { toys }\end{array}$ & $\begin{array}{c}\text { Shoe } \\
\text { repairs }\end{array}$ & $\begin{array}{c}\text { Trad } \\
\text { med }\end{array}$ & Others & $\begin{array}{c}\text { Total } \\
\%\end{array}$ \\
\hline Umtata & 6.7 & 3.2 & 8.4 & 3.2 & 1.0 & 0 & 0 & 22.5 \\
\hline B'wth & 1.7 & 1.7 & 3.2 & 1.2 & 0.4 & 0.2 & 0 & 8.4 \\
\hline $\begin{array}{c}\text { East } \\
\text { London }\end{array}$ & 15.6 & 14.6 & 7.4 & 6.1 & 0.2 & 0.8 & 0 & 45 \\
\hline KWT & 7.4 & 7 & 5.0 & 3.4 & 0.4 & 0.6 & 0.6 & 24 \\
\hline TOTAL & 31.4 & 26.5 & 24 & 13.9 & 2.0 & 1.6 & 0.6 & 100 \\
\hline
\end{tabular}

Activity-wise, 31.4 per cent of the traders surveyed dealt with perishable goods, such as fruits and vegetables. Regionally, 6.7 per cent were based in Umtata, 1.7 per cent in Butterworth, 15.6 per cent in East London and 7.4 per cent in KWT (Table 6). With regard to clothing items, 24 per cent of vendors were involved in this activity, with Umtata accounting for 8.4 per cent, Butterworth 3.2 per cent, East London 7.4 per cent and KWT 5 per cent. 


\subsection{Capital}

\subsubsection{Initial Capital}

The initial amount of capital to commence a street business varied significantly among the individuals, ranging from R20 to R7000. Over half of the traders ( 57.5 per cent) started off with an initial capital of R100 or less, another 17 per cent started with a capital of R101- R200, and only 6 per cent had a launch capital of over R1000 (Table 7). The mean launch capital was R343. A significant correlation was found to exist between initial capital and standard of education $(r=0.33 ; p=0.04)$, suggesting that even among the street vendors, individuals with higher levels of education tend to start in business with high levels of capital. The more skilled vendors may have access to loans from financial institutions.

\section{Table 7 Distribution of launch capital}

\begin{tabular}{|c|c|}
\hline Capital (Rands) & Frequency (\%) \\
\hline 100 and less & $273(57.5)$ \\
\hline $101-200$ & $81(17.1)$ \\
\hline $201-300$ & $20(4.2)$ \\
\hline $301-400$ & $15(3.2)$ \\
\hline $401-500$ & $28(5.9)$ \\
\hline $501-600$ & $9(1.9)$ \\
\hline $601-700$ & $1(0.2)$ \\
\hline $701-800$ & $5(1.1)$ \\
\hline $801-900$ & $1(0.2)$ \\
\hline $901-1000$ & $13(2.7)$ \\
\hline $1001+$ & $29(6.1)$ \\
\hline TOTAL & $475(100)$ \\
\hline
\end{tabular}

\subsubsection{Sources of launch capital}

The initial capital of more than half ( 52.6 per cent) of the pavement traders came from their own savings (Table 8). Friends and family financially assisted another 40 per cent of the members. A few female operators ( 0.8 per cent) succeeded in raising finance from banks, the Eastern Cape Development Agency $(\mathrm{ECDA})$, and the rest from informal lenders and other formal traders. However, proportionately more women than men started off their trading from accumulated personal savings ( 52 per cent) and family funds ( 31 per cent). 
Table 8 Sources of starting-up capital

\begin{tabular}{|c|c|c|c|c|c|c|}
\hline Gender & $\begin{array}{c}\text { Personal } \\
\text { savings }\end{array}$ & $\begin{array}{c}\text { Family } \\
\text { funds }\end{array}$ & Friends & $\begin{array}{c}\text { Bank } \\
\text { loans }\end{array}$ & $\begin{array}{c}\text { ECDA } \\
\text { loans }\end{array}$ & $\begin{array}{c}\text { Other } \\
\text { loans }\end{array}$ \\
\hline Female & $\begin{array}{c}180 \\
(37.9 \%)\end{array}$ & $\begin{array}{c}118 \\
(24.8 \%)\end{array}$ & $\begin{array}{c}26 \\
(5.5 \%)\end{array}$ & $\begin{array}{c}2 \\
(0.4 \%)\end{array}$ & $\begin{array}{c}2 \\
(0.4 \%)\end{array}$ & $\begin{array}{c}18 \\
(3.8 \%)\end{array}$ \\
\hline Male & $\begin{array}{c}70 \\
(14.7 \%)\end{array}$ & $\begin{array}{c}38 \\
(8 \%)\end{array}$ & $\begin{array}{c}12 \\
(2.5 \%)\end{array}$ & 0 & 0 & $\begin{array}{c}9 \\
(1.9 \%)\end{array}$ \\
\hline TOTAL & $\begin{array}{c}250 \\
(52.6 \%)\end{array}$ & $\begin{array}{c}156 \\
(32.8 \%)\end{array}$ & $\begin{array}{c}38 \\
(8 \%)\end{array}$ & $\begin{array}{c}2 \\
(0.4 \%)\end{array}$ & $\begin{array}{c}2 \\
(0.4 \%)\end{array}$ & $\begin{array}{c}27 \\
(5.7 \%)\end{array}$ \\
\hline
\end{tabular}

Although only a few of the street vendors obtained loans from financial institutions, this does not suggest that they were not integrated into the formal sector. Of the street traders, only about 8 per cent have a savings account with the post office, another 42 ner cent have a similar account with banks, but about half of them do not have any savings account. This paucity of savings among the traders reflects that street vending activity is a highly over-traded activity with low productivity, generating very little returns to many operators.

With regard to sources of supply, 97 per cent of the traders procure from wholesalers and retailers; and the remainder source their products themselves, from farming. Credit facilities are obtained by only a handful few street traders ( 2 per cent). While nearly all the respondents ( 98 per cent) buy stock on a cash basis from suppliers, a significant number of them ( 31 per cent) sell on credit, ranging from one week to one month, to their customers, who are mostly low income eamers.

Financial records are essential for making business decisions. Without a record system to keep track of the operating results, street vendors may lose direction of their meagre assets and liabilities. However, of the surveyed vendors, 79 per cent do not keep any records. While about a third of the traders operate on credit terms, only 18 per cent claimed to keep a cash register; a high proportion of the latter group have had an education above standard 5.

\subsection{Income}

\subsubsection{Business sales}

Daily sales vary significantly among the traders, depending partly on the nature of activity and location. Obviously there are days when sales turnover is usually good, such as at the end of the month after the payday. The traders in fruit and vegetables, traditional medicine and shoe repairs earn a little amount of money, 
ranging from $\mathrm{R} 20$ to $\mathrm{R} 80$ a day. The traders dealing in clothing, food and ornaments eam about R200 and more per day. These are the ones having the potential to save some money, after meeting business expenses.

\section{Table 9 Average daily sales taking}

\begin{tabular}{|c|c|}
\hline Amount (Rands) & Frequency (\%) \\
\hline $20-40$ & $130(28.4 \%)$ \\
\hline $41-80$ & $141(29.7 \%)$ \\
\hline $81-120$ & $64(13.5 \%)$ \\
\hline $121-160$ & $23(4.8 \%)$ \\
\hline $161-200$ & $35(7.4 \%)$ \\
\hline $201+$ & $8217.3 \%)$ \\
\hline
\end{tabular}

After subtracting weekly expenses, the profit, on average, made from street vending is rather low for most of the operators. About one third ( 36 per cent) claimed to have a weekly profit of between R20 and R40 and only 17 per cent had a net income, on average, of R240 or more (Table 9).

\subsubsection{Other Sources of Income}

Virtually all individuals have responsibilities and needs to meet from their limited income. The overwhelming majority ( 81 per cent) of the street operators asserted that they do not get enough money from their business to support their family, and did not have any other alternative source of income. However, 4 per cent of the vendors could augment their household income through spouse's salaries, another 11 per cent through parents' pensions, and just under 1 per cent through remittances. The low income earned from street trading clearly reflects that the urban informal sector is merely a survivalist strategy for most operators.

\subsection{Job Creation}

Government policy on the informal sector is premised on the ground that it has high prospects to create jobs with low capital investment. However, results of this study indicate that the job creation ability of the informal secto is rather low; 78 per cent of the businesses created personal employment for the selfoperator only (Table 10). In only 16 per cent of the ventures, two jobs were created, one for the operator and another for a wage eamer. Only 5 per cent (27 cases) of the surveyed operators were able to employ two or more people. Out of 15 people offering employment to self and to two additional individuals, a marginally larger proportion of male traders was able to employ two other individuals. In the higher employment category of at least five persons, women 
( 1.5 per cent) had a relative edge over men $(0.4$ per cent). The wage offered varied from $\mathrm{R} 70$ a week to $\mathrm{R} 450$ a month.

Table 10 Employment creation

\begin{tabular}{|c|c|c|c|c|c|c|}
\hline Gender & Self & $\begin{array}{c}\text { Self \& 1 } \\
\text { person }\end{array}$ & $\begin{array}{c}\text { Self \& 2 } \\
\text { persons }\end{array}$ & $\begin{array}{c}\text { Self \& 3 } \\
\text { persons }\end{array}$ & $\begin{array}{c}\text { Self \& 4 + } \\
\text { Persons }\end{array}$ & Total \\
\hline Female & 2 & 57 & 7 & 2 & 7 & 346 \\
$(57.5 \%)$ & $(12 \%)$ & $(1.5 \%)$ & $(0.4 \%)$ & $(1.5 \%)$ & $(73 \%)$ \\
\hline \multirow{2}{*}{ Male } & $\begin{array}{c}97 \\
(20.4 \%)\end{array}$ & $\begin{array}{c}21 \\
(4.4 \%)\end{array}$ & $\begin{array}{c}8 \\
(1.7 \%)\end{array}$ & $\begin{array}{c}1 \\
(0.2 \%)\end{array}$ & $\begin{array}{c}2 \\
(0.4 \%)\end{array}$ & $\begin{array}{c}129 \\
(27 \%)\end{array}$ \\
\hline \multirow{2}{*}{ TOTAL } & $\begin{array}{c}370 \\
(77.9 \%)\end{array}$ & $\begin{array}{c}78 \\
(16.4 \%)\end{array}$ & $\begin{array}{c}15 \\
(3.2 \%)\end{array}$ & $\begin{array}{c}3 \\
(0.6 \%)\end{array}$ & $\begin{array}{c}9 \\
(1.9 \%)\end{array}$ & $\begin{array}{c}475 \\
(100 \%)\end{array}$ \\
\hline
\end{tabular}

\subsection{Problems and Needs}

The major problems, as perceived by the street traders, affecting their business are related to infrastructure, security and market constraints. For 30 per cent of the operators, lack of shelters was a major problem (Table 11). About 16 per cent mentioned lack of security, as they have been victims of crimes and robberies while conducting street vending. Another 16 per cent mentioned that business was not progressing on account of competition and demand constraints. However, just over a quarter indicated that they have no problem with their business.

\section{Table 11 Problems of street vendors}

\begin{tabular}{|c|c|}
\hline Nature of Problems & Frequency (\%) \\
\hline Lack of shelters & $142(29.9 \%)$ \\
\hline Lack of security & $74(15.6 \%)$ \\
\hline Competition & $79(16.6 \%)$ \\
\hline City police & $12(2.5 \%)$ \\
\hline Foreigners & $5(1.1 \%)$ \\
\hline Limited space & $15(3.2 \%)$ \\
\hline Others & $16(3.4 \%)$ \\
\hline Noproblem & $132(27.8 \%)$ \\
\hline TOTAL & $475(100 \%)$ \\
\hline
\end{tabular}

When it comes to assistance needed for advancing street vending, 40 per cent indicated the need for finance and loans. Another 24 per cent mentioned the need for shelters to be provided by the municipality and for which they would be prepared to pay a rental, 2 per cent expressed the need for greater security, and 
24 per cent indicated that they wanted employment. However, none had suggested the need for entrepreneurship training.

\subsection{Future Prospects}

The vendors were asked to rate the prospects of their businesses. The ratings are categorised as poor, fair, good and growing, and excellent. According to the street entrepreneurs themselves, the prospects are not that encouraging, but these are realistic perspectives. Over half ( 54 per cent) rated their businesses as poor, 34 per cent as fair, 12 per cent as good and growing, only one male trader rated his business as excellent (Figure 3). Proportionately, men seem to rate their street selling activities more positively than women. Of the 129 male vendors, 45 per cent, 37 per cent and 17 per cont classified the business as poor, fair and good respectively.

\section{Figure 3 Business prospects}

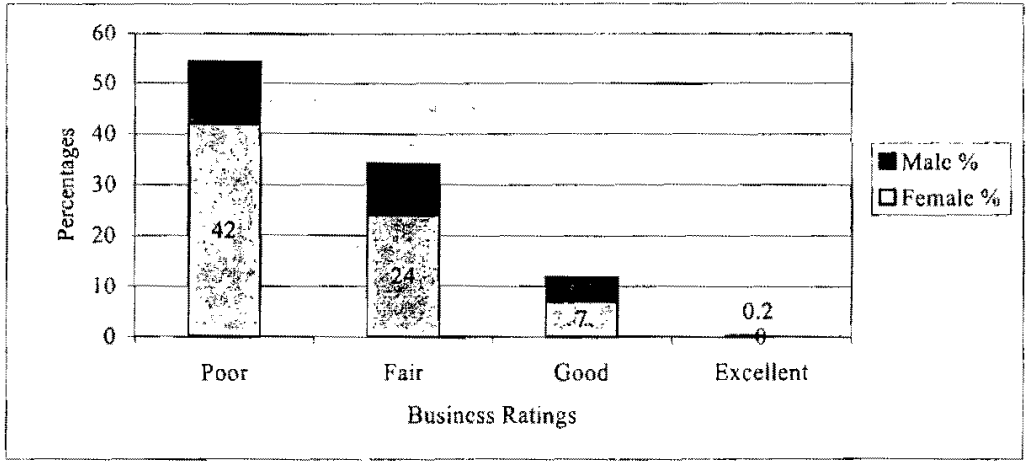

\section{POLICY IMPLICATIONS AND CONCLUSION}

The majority of the respondents came from the urban poor, for whom street vending made a contribution, albeit an often insufficient one, to family subsistence. They had been drawn into the informal economy because of a lack of employment opportunities in the Eastern Cape, and in South Africa at large. Clearly, any policy directed towards the informal sector must be formulated on the basis of an awareness of its dynamic potential. The data reviewed here have shed light on the question of whether one could consider this type of activity as a conduit for entrepreneurship rather than a mere survival strategy.

It seems highly unlikely that in the next few years a substantial number of high 
profile entrepreneurs would emerge from this mass of survivalist traders. Most of them (84 per cent) are not committed to staying in the informal sector if an alternative formal employment should emerge. Only 15 per cent of the street traders indicated that they would prefer to stay on with their business even if a formal job with attractive prospects is offered. Probably, it is from this latter group of traders that job opportunities might emerge in the future. They are the ones who might create more vibrant enterprises in the informal economy and perhaps graduate to more sustainable ventures in the formal sector as business conditions improve over time provincially and nationally.

For most of the street traders, however, the informal economy is not a conduit to entrepreneurship, but a survival strategy. The respondents have, on average, spent far more time in the informal economy as street vendors ( 5.2 years) than in the formal sector as wage labour (2.4 years). Accordingly, one may infer that eking out an existence through street trading has become almost an entrenched way of life for the majority, even though they earn uneconomic rewards for the long hours they put into their ventures.

From an informal sector development standpoint, the way forward for the street vendors is to transform their ventures into more value-adding operations that can provide sustainable livelihoods for themselves, and in due course jobs for others. From a development policy standpoint, support measures should focus on identifying their short- and medium-term business development needs. Findings of the survey suggests that there are quite good prospects for helping street vendors to surmount some of the obstacles constraining the development of their businesses. Based on the actual demand of the operators themselves, the measures which would be most helpful would involve a combination of better access to finance, help with the trading infrastructure and contributions to streetlevel security.

\section{ENDNOTE}

A revised version of this paper was presented at the $13^{\text {th }}$ South African Entrepreneurship \& Small Business Association (SAESBA) Conference, 13 August 2001, Caesars, Johannesburg. The author gratefully acknowledges funding received from the HSRC for this research and would like to thank an anonymous referee and Steve Butters of the University of Middlesex, UK for their helpful comments. 


\section{REFERENCES}

1 ABEDIAN, J. \& DESMIDT, M. (1990) "The Informal Economy in South Africa", South African Journal of Economics, 58 (4).

2 AGARWALA, R. (1990) "Preface to World Bank, Long-term Perspective Study", Background Papers, Sub-Saharan Africa: From Crisis to Sustainable Growth, Washington.

3 BAUMOL, W. J. (1990) "Entrepreneurship: Productive, Unproductive and Destructive", Journal of Political Economy, 98(5): 893-921.

4 BUREAU FOR MARKET RESEARCH (1996) "South Africa's Informal Sector", 1/96, Unisa, Pretoria.

5 CENTRAL STATISTICAL SERVICE (1995) October Household Survey, Statistical Release P0317, Pretoria.

6 ELSON, D. \& PEARSON, R. (1997) "The Subordination of Women and the Internationalisation of Factory Production", in The Women, Gender and Development Reader, Visvanathan, $\mathrm{N}$, et al. (eds.), Zed Books Limited, London: 177-90.

7 FINANCAIL MAIL (2001) "Employment Figures Down Again", June 29: 209-14.

8 FRIEDMAN, M. \& HAMBRIDGE, M. (1991) "The Informal Sector, Gender and Development", in South Africa's Informal Economy (eds.) Preston-Whyte, E. and Rogerson, C., OUP, Cape Town: 160-80.

9 ILO (International Labour Organisation) 1972 Employment, Incomes and Equality: A Strategy for Increasing Productive Employment in Kenya, ILO, Geneva.

10 INGHAM, B. (1995) Economics and Development, McGrawHill, London.

11 KAPLINSKY, R. (1990) "A Policy Agenda for Post-apartheid South Africa", Transformation, 12: 42.

12 KIRSTEN, M. \& SINDANE, M. (1994) 'The Informal Sector and Small Business: A South African Case Study', in Venter, M. (ed.) Prospects for Progress: Critical Choices for Southern Africa, Maskew Miller Longman, Cape Town.

13 LOOTS, E. (1998) "Job Creation and Economic Growth", The South African Journal of Economics, 66: 319-36.

14 MAHADEA, D. (2001) "Similarities and Differences between Male and Female Entrepreneurial Attributes in Manufacturing Firms in the Informal Sector Sector in the Transkei", Development Southern Africa, 18(2): 18999.

15 NATTRASS, N. (1987) "Street Trading in Transkei - A Struggle Against Poverty, Persecution and Poverty", World Development, 15: 861-75.

16 PEATTIE, L. (1987) "An Idea in Good Currency and How it Grew: The Informal Sector", World Development, Vol. 15 (7).

17 PRESTON-WHYTE, E. \& ROGERSON, C. (eds.) (1991) South Africa's 
Informal Economy, OUP, Cape Town.

18 PRESTON-WHYTE, E. \& NENE, S. (1991) "Black Women and the Rural Informal Sector", in Preston-Whyte, E. and Rogerson, C. (eds.) South Africa's Informal Sector, OUP, Cape Town.

19 SARB, (1988/2000/01) South African Reserve Bank, Quarterly Bulletins, No. 210-216 and 219, Pretoria.

20 STATISTICS South Africa (2001) Labour Force Survey: February 2001, Statistical Release P0210, Pretoria: Statistics South Africa.

21 THE ECONOMIST (2001) "The Worst Way to Lose Talent", 10 February: 75.

22 THE ECONOMIST (1999) "Funky for a Day at Least", 16 June: 64.

23 WORLD BANK (1990) Annual Report, 1990. World Bank. Washington, D.C. 